CCRL-

PREPRINT

UCRL- -97155

DEB7 014252

\title{
USE OF A TRANSFECTED AND AMPLIFIED DROSOPHILA HEAT SHOCK PROMOTER CONSTRUCTION FOR INDUCIBLE PRODUCTION OF TOXIC MOUSE C-MYC PROTEINS IN CHO CEL S
}

F.M. Wurm, K.A. Gwinn, O. Papoulas, M. Pallavicini, and R.E. Kingston

\section{BIONEDICAL SCIENCES DIVISION}

This paper was prepared for submittal to

Proceedings oi the ESACT-Meeting Israel

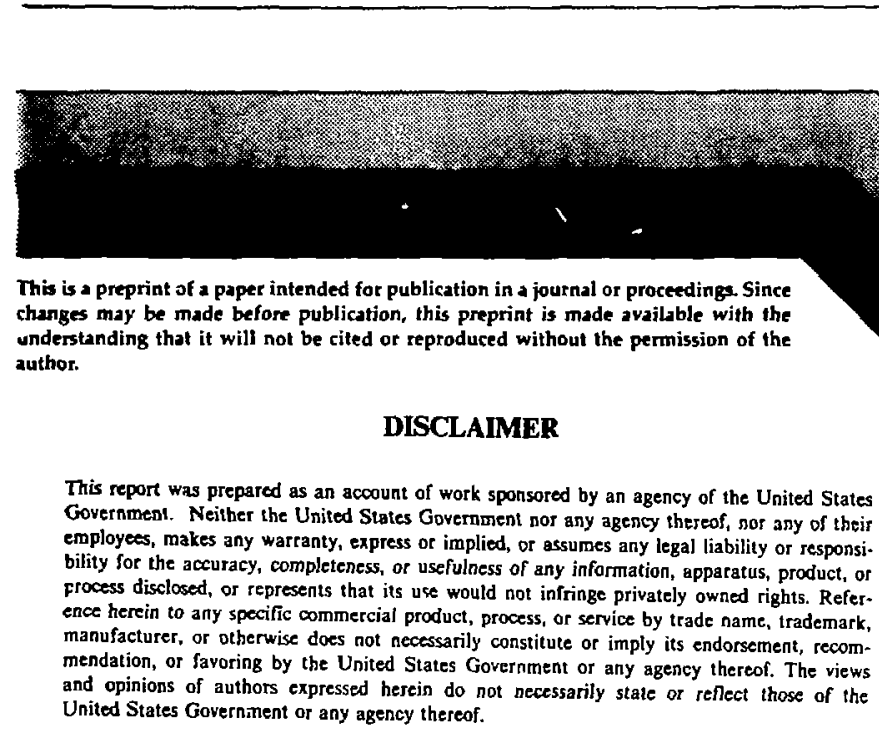

This report was prepared as an account of work sponsored by an agency of the United States Government. Neither the United States Government nor any agency theseof, so: any of their cmployees, makes any warranty, express or implied, or assumes any legal liability or responsibility sor the accuracy, completeness, or usefulness of any information, apparatus, product, or eress disclosed, or represents that its uce would not infringe privately owned rights. Refer. ence herein to any specific commercial product, process, or service by trade name, trademark, (1) recomUnerest or any agency thereof. The views United States Government of any agency thereof. 


\section{DISCLAIMER}

This document was prepared as an account of work spansored by an ageacy of the Uaited States Goxemment. Neither the United Stales Government aor the Universing of Californis nor any of their employees, makes my warranty, express or implied, or assumes any legal liability or responalbility for the accuracy, completeness, of asefolness of any information, apparatus, prodsct, of precess disckosed, of represents that its we would not iwfinge privately owned rights. Reference herein to any specifit commercinl producks, process, or service by trade name, trademark, manulactwrer, or of herwise, does net necessarily constitute or inply its endorsement, recommendation, or favoriag by the United States Government or the University of Califorais. The views and opinions of authors expressed herein do not necesserily state or reilect those of the United States Government or the University of Californien, and shall not be wed for advertising or product endorsement purposes. 
Use of a transfected and amplified Drosophila heat shock promoter construction for inducible production of toxic mouse c-myc proteins in CHO cells.

Florian M. Wurm*, Katrina A. Gwinn, Ophella Papoulas, Maria Pallavicinit* and Robert E. Kingston. Mass. Gen. Hospital, Dept. Mol. Biology, Boston MA 02114, *presert address: Genentech, Inc., 460 Point San Bruno Blvd., South San Francisco, CA 94080, USA. *tLawrence Livermore Lab., Livemore, CA 94550.

\section{ABSTRACT}

After transfection and selection with methotrexate, CHO cell lines were established which contained up to 2000 copies of an expression vector for c-myc protein. The vector contained the Drosophila heat shock protein 70 (hsp70) pronoter fused with the coding region of the mouse c-myc gene. Incubation of cells for up to 3 hours at $43^{\circ} \mathrm{C}$ resulted in at least a 100 -fold induction of recombinant c-myc mRMA. When cells were shifted back to $37^{\circ} \mathrm{C}$, within 1 to 4 hours this RNA was translated into protein to yleld about 250 $\mu g$ per $10^{9}$ cells. Cells died a few hours later, suggesting that high concentrations of intracellular c-myc are cytotoxic. 
The gene of interest was introduced and amplified to high copy numbers in a silent form. The presence of so many Drosophila hsp70 promoters in the cells did not impair their induction. The method described here may provide a general tool for expression of proteins, especially those unsuitable for constitutive overproduction due to toxicity or other factors.

\section{INTROOUCTIan}

A number of mammalian or viral proteins of pharmaceutical interest have been produced in Escherichia coli and yeast using inducible expression vectors $(1,2)$. These vectors were chosen because the proteins, when expressed constitutively, proved to be toxic to the microbial host or inhibited its' growth rate.

In most transfected mamalian cells, production of proteins of interest has been accomplished by use of constitutive expression vectors, often having viral components (3-10). Inducible expresion systems, however, have certain advantages: Firstly, noninduced cells are expected to have higher growth rates because more of their metabolic activity can go into housekeeping functions. Secondly, :here might be a substantial class of mamalian proteins whose high level expression is toxic to host cells. Thirdly, it might be desireable to initiate the formation of the product at will, especially in an industrial situation with hardware and working schedule constraints. Although of increasing interest, only a few inducible vectors have been used so far in mammalian cells (11-16). We describe here the Drosophila heat shock protein 70 promoter (hsp70 promoter) and its molecular biology in stably transfected cell lines. We believe it is the most effective inducible promoter 
so far evaluated in mamalian cells. Its potential as a general expression vector in mamnalian cells is discussed.

\section{RESULTS ND DISCUSSIOH}

\section{General roarks}

The Drosophila hsp70 promoter originates from a genomic fragment containing one of the multiple heat shock loct in Drosophila melanogaster $(17,18)$. When used to drive the expression of a marker gene in mammalian cells, this promoter has an extremely low level of transcription at $37^{\circ} \mathrm{C}(19)$. Even in cells containing up to $4 \times 10^{4}$ copies of a heat shock promoter, a basal level of transcription could not be detected (20). When cells were shifted to $43^{\circ} \mathrm{C}$ for 60 minutes or more, heat shock mRKA is induced at a rate equal to or greater tilan that of the strong sv40 promoter $(19,20)$.

The product of the protooncogene c-myc is suspected to be toxic to mamalian host cells when overexpressed constitutively. This is based on the assumption that the expression of a protein with regulatory functions is controlled in a strict and sensitive way - so constitutive high level expression would create an imbalance in the cells' regulatory mechanisms. C-myc is highly conserved in vertebrates; several lines of evidence suggest that the gene and its products play an important role in mechanisms involved in control of cell growth and differentiation $(21,22)$. In many instances the gene is responsible for the generation of malignant tumors after chromosomal rearrangements or when activated by retroviruses (23-26). The nature and function of the protein itself remains obscure due to its extremely low expression level in cells. Attempis to overexpress c-myc in mamalian cells using constitutive 
pronoters led either to very poorly growing refractile cells or to cell lines in which the gene was partially or totally deleted (27). In order t? inducibly express the mouse c-myc protein we chose to transfect and stably integrate the c-myc gene under the control of the Dr. hsp70 promoter ipto dihydrofolate reductase (DHFR) deficient Chinese Hamster Ovary cells (CHO) (28). These cells are widely used for production of exogeneous mammalian or viral proteins (3-7). This is due to two major advantages of these cells over other systems. First, transfected DNA usually becomes integrated into the genome, thus enabling the establishment of stable cell lines (30). Second, using the gene for the enzyme dihydrofolate reductase as a selectable marker and treating cell populations with the DHFR antagonistic drug methotrexate, the integrated DNA can be amplified many times, generally leading to elevated expression levels $(29,30,3-6)$.

\section{Construction of expression vectors}

To produce high yieids of the c-myc protein, we transfected CHO-DUKX cells (28) with the vector pHS-Myc. This vector (see fig. 1) was made with a promoter containing a DNA fragment of 850 bp whose essential elements are from 5' to 3': four "heat shock boxes", conserved sequences of 25 bp which have been found to be crucial for heat inducibility $(19,33,34)$, the TATA box, the transciption start site and a stretch of 88 bp of the nontranslated leader sequence of the hsp70 gene. This part of the heat shock leader contains one of two "consensus sequences", which are conserved in various heat shock genes. The function of these sequences has not yet been elucidated (32). A $4.5 \mathrm{~kb}$ genomic mouse c-myc fragment consisting of exon 2 and 3 together with an Intron and nontranslated $3^{\prime}$-sequences was linked to the promoter. The first exon of mamalian and avian c-myc genes contains multiple stop condons in all 
reading frames and is regarded as noncoding $(35,36)$. In our construction, the first translation start codon following the transcription start site of the heat shock promoter is that of the c-myc gene (fig. 1). The selectable marker was provided by a second vector in which the expression of the c-DNA of a mouse DHFR gene was driven by the constitutive Adeno EII promoter (PCVSVEII-DHFR, 37). The piasmid pHS-Myc and PCVSVEII-DHFR wers mixed in a ratio of $5: 1$ and transfected. Recombinant clones were pfcked after two weeks of growth in selective medium, propagated separately into $100 \mathrm{~mm}$ petri dishes, and then subjected to increasing concentrations of methotrexate. After six months 4 cell lines resistant to $320 \mathrm{p}$ molar concentrations of methotrexate were established.

Copy nuber and chrowoscal location of transfected beat shock-c-uc construction

To test whether the transfected c-myc DNA had been integrated into the genome and amplified during methotrexate selection a Southern experiment was performed. Genonic DNAs were isolated, restricted, electrophoretically separated, and transferred to nitrocellulose. The filters were probec with in vitro transcribed P32-labelled c-myc specific RHK. As can be seen in fig 2 , each of the 4 lines contained c-myc sequences, though to differing degrees. By comparing the intensities of the signals with those generated by dflutions of the plasinid pHS-Myc, the copy number of the construction in each of the four lines was estimated. The line 4 HSMyc contained about 900 coples, 5AHSMyc 2000 copies, 5BHSMyc about 100 copies and 6HSMyc about 2500 coples. The additional bands generated by the latter 1 ine indicate DNA rearrangements which occurred probably early in the selective procedure and which were ampliffed together with the intact construction. 
In the line 5AHSMyc the chromosomal location of the hsp70/c-myc construction has been investigated by using a biotinylated c-myc probe in in-situ hybridizations of metaphase chromosomes. The amplified heat shock c-myc construction was found to be located on the long arm of chromosome 2. 1data not shown).

\section{Inducibility and arintenance of recobinant c-myc transcripts}

Cells were induced by feeding them with $43^{\circ} \mathrm{C}$ prewarmed medium and keeping them at that temperature for 1 to 2 hours. To measure the extent of the induction, RNA from induced and uninduced cells was isolated and hybridized to in vitro transcribed c-myc specific RNA. The hybrid molecules were digested with RNase to remove single stranded regions and subjected to polyacrylamide gel electrophoresis. The result of this experiment is shown in fig. 3a. Each of the cell lines exhibited a clear induction of the c-myc mRKA (lanes 1-10). It is important to note here that not a trace of a signal could be detected from cells kept at $37^{\circ} \mathrm{C}$ - even after prolonged exposures of the film. The induced concentrations of recombinant mRNA were proportional to the copy number of the introduced construction. Therefore there did not appear to be an insufficiency of cellular factors responsible for the induction of the hsp70 promoter region, even in the most highly amplified lines. This is shown in Fig. 3a, Ianes 11-16, where the RNA from the line 5AHSMyc was analyzed using cells at different levels of methotrexate selection. We estimate that the degree of induction of the Drosophila hsp70 promoter in the amplified lines is at least 100 fold, because we could not detect a basal level of expression in uninduced lines. A similar kind of experiment was done to investigate how long after heat shock recombinant RNA remained detectable inside the cells. 
The cells were induced at $43^{\circ} \mathrm{C}$ for 2 hours and then shifted back to $37^{\circ} \mathrm{C}$ for up to 3 hours. RMA isoleted after 1,2, and 3 hours was hybridized and analyzed as described before. Recombinant mRNA was found even 3 hours after shifting the cells back to $37^{\circ} \mathrm{C}$ (Fig. $3 \mathrm{~b}$ ). We have not determined whether this was due to high stability of the recombinant c-myc RNA, cuntinued high promoter activity or a combination of these effects. Recently, Simcox et al. (38) found that a deletion of the 3 'end of hsp70 mRNA increased the stability of the mRNA during the recovery period after heat shock. Our construction did not have the hsp70 3 'end either, hence the maintenance of the recombinant hsp70/cmyc mRNA may be due to the fact that it did not contain sequences responsible for rapid degradation of nomal heat shock messages during recovery.

c-myc protein synthesis in induced recombinant cell lines

Initialiy, cell lines were investigated for c-myc protein synthesis imedfately after a 2 hour heat shock at $43^{\circ} \mathrm{C}$. At that time point no $\mathrm{C}$-myc protein could be detected as judged by labelling with (35S) methionine or by immunoblotting. When cells were allowed to recover at $37^{\circ} \mathrm{C}$ for extended periods, however, c-myc protein was detected by both methods. The level of protein increased rapidly during the first 2-3 hours of recovery (fig. 4), but continued to increase only slightly over the next 6 hours. Usually cells were harvested for detection and isolation of c-myc after 3 hours of recovery.

Three protein bands with apparent molecular weights of $64,000,66,000$ and 74,000 were recognized by monoclonal and polyclonal antibodies ralsed against a portion of the human c-myc protein that is conserved in mouse c-myc (42). 
The smaller two of these were seen in previous studies $(39,40)$. It is not clear whether the third species with a molecular weight of $74,00 n$ is a form of c-myc present in normal cells or is an aberrant form. It is possible, for example, that overproduction of c-myc results in some modification, such as ubiquitination (43), not relevant to the normal biology of the c-myc protein. The cell line with the higher copy number (5AHSMyc) produced at least twice the amount of c-myc protein as the line 4HSMyc. In experiments using metabolic labelling of cells with 35S-methionine, it was found that protein synthesis in the recombinant lines during recovery after heat shock was reduced to about $20 \%$ of the values seen in the nonrecombinant parental line which was induced in the same way. This may have been due to the suspected c-myc toxicity on the cells metabolic pathways. In spite of this finding, the intensity of the c-myc band in SDS/polyacryianide gels revealed that this protein was one of the most actively synthesized during the recovery period (fig. 4b, lane 4). In cells labelled with orthophosphate (32P), all three recombinant c-myc species were phosphorylated (fig $4 \mathrm{~b}$ ), indicating proper modification of these molecules. All avian and mamalian c-myc proteins analyzed so far have been found to be phosphorylated $(41,42,44)$. It should be noted that the pure genetic information of the c-myc gene would produce an unnodified protein with a molecular weight of 48,000 D. It is not known why the c-myc proteins migrate in SDS/polyacrylanide gels at the molecular weight range of $62000 \mathrm{D}$ to $68000 \mathrm{D}(45)$. Whatever the basts of this anomalous migration, the CHO cells provided a means to produce a protein which by all known criterla appeared identical to authentic c-myc protein. 
In immunoblot experiments we estimated the yields of recombinant c-myc produced by ihese cells relative to a standard of purified c-muc protein produced in insect cells (kindly donated by $R$. Chizzonite at Hoffman LaRoche). We estimated the amount of c-inyc protein to be 200 to $300 \mu \mathrm{g}$ per $10^{9} \mathrm{cell} \mathrm{s}$. Theoretically, this corresponds with a specific productivity of about 2 fg per cell per day. He have developed a purification scheme for c-myc protein and are in the process of isolating larger amounts for further analysis.

\section{Overproduction of cayc protein is cytotoxic.}

It was suspected that constitutive overproduction of c-myc is toxic. We tested, therefore, the effect of the induced overproduction of this protein on the viabllity of the cells. Parental and recombinant lines were plated at about $10 \%$ confluency, kept at $37^{\circ} \mathrm{C}$ for 3 hours, then either heat shocked at $43^{\circ} \mathrm{C}$ for 2 hours and then returned to $37^{\circ}$ for a period of 3 days, or, kept at $37^{\circ} \mathrm{C}$ all the time. No living cells were left on heat shocked dishes of any of the recombinant lines, as well as both the heat shock and control dishes of the parental line, were confluent. An example of this experiment is shown in fig. 5a.

Microscopic examination of the recombinant cell lines during the recovery period showed detachment and slow deterioration of cells and no further cell divisions (fig. 5b). This may have beer the result of a general cytotoxic effect of the high c-myc protein levels. Alternatfvely, the recombinant 
hsp70/c-myc constructions may block or slow the nomal cellular response to heat. Two observations favor the former possibility: Firstly, in Sos-polyacrylamide gels containing samples from the recombinant cells, the nomal heat shock proteins were observed at their usual intensity relative to the other proteins (fig. 4). Therefore, there was a proper induction of the endogeneous heat shock genes despite the presence of so many recombinant heat shock genes. Secondly, as mentioned earller, recombinant lines containing high constitutive levels of c-myc are extrenely difficult to establish in culture and have an abnormal and labile phenotype. Henze there may be a continuous selection against cells which express the c-myc protein at high levels, due to the toxicity of the protein itself.

\section{A general method for inducible expression in emalian cells?}

We chose to overexpress the mouse c-myc protein in CHO cells for two reasons: Firstly, we belleved that this approach would enable us to obtain this protein in an authentic form in sufficient quantities to allow detailed analysis. Secondly, it was hoped the experiments would show whether the Drosophila hsp70 promoter could be used as a general tool for obtaining proteins which interact adversely with the mammalian cell host. He have demonstrated that the Drosophtla hsp70 promoter is highly inducible even when amplified. The control exerted by this promoter was so tight that even after a 2000 fold amplification no protein was detected without an inducing heat shock. The expression levels of other marmalian inducible promoters, I1ke MMTV-LTR, human metallothionein and interferon promoter are lower than those of the Drosophila hsp70 promoter when induced and they have higher levels of basal transcription in the range of 12 to $30 x$ of the induced activity $(11-16)$. 
This may present an obstacle for the expression of toxic proteins, especially after amplification. Amplification methods presently used can often lead to at least 50 copies of the introduced genes. Under these conditions, a promoter with only $1 \%$ of its maximal activity would, without induction, give moderately high mRNA levels constitutively, which could prohibit expression of toxic proteins of interest.

A third reason to favor the Drosophila hsp70 promoter was the observation that the growth of the $\mathrm{CHO}$ cells was not impaired by the introduction and amplification of the DNA constructs. This again is probably due to the tightness of the promoter at $37^{\circ} \mathrm{C}$ preventing diversion of cellular metabolic and housekeeping functions thus permitting maximal growth rates. In large scale situations, where mammalian cells are used for production of proteins of pharmaceutical interest (46), cell growth and medium consumption rates are very important factors and economic advantages will accrue where they can be influenced positively. Thus the Erosophila hsp70 promoter might also be valuable for non-toxic proteins. It should be emphasized that the use of this promoter is not restricted to CHD cells but is functional in various other mammalian substrates as previously shown $(19,33,47)$.

In summary, we have described a promoter and its use for the induced production of a rare protein in manmalian cells. This protein is thought to play a key role in the metabolism of cells and seems to exert a cytotoxic effect when expressed to very high levels for prolonged periods. We think the tightness of this promoter at $37^{\circ} \mathrm{C}$ and its degree of inducibility in highly amplified lines as shown will prove applicable for inducible expression of a variety of other mamalian proteins as well. 


\section{ACKNOWLEDGMENTS}

Work performed under the auspices of the U.S. Department of Energy by the Lawrence Livermore National Laboratory under contract number W-7405-ENG-48. 


\section{LITERATURE}

1. Remaut, E.. Stannsens, P. and Fiers, H. (1981). Plasmid vectors for high-efficiency expression controlled by the PL-promoter of coliphage lambda. Gene 15, 81-94.

2. Tuite, M.F., Dobson, M.J., Roberts, N.A., King, R.M., Burke, D.C., Kingsman, S.M., and Kingsman, A.J. (1982). Regulated high efficiency expression of human interferon-alpha in S. cerevisiae. EMBO J. 1 , 603-608.

3. Kaufman, R.J., Wasley, L.C., Spilitiotes, A.J., Gossels, S.D., Latt, S.A., Larsen, G.F., and Kay, R.M.: Coamplification and coexpression of human tissue-type plasminogen activator and murine dihydrofolate reductase sequences in Chinese hamster ovary cells. Mol. Cell. Biol. $5,7,1750-1759(1985)$.

4. Lau, Y.F., Lin, C.C., and Wai Kan, Y.: Amplification and expression of human alpha globin genes in Chinese hamster ovary cells. Mol. Cell. Biol. $4,8,1469-1475$ (1984).

5. Scahill, S.J., Devos, A., Van der Heyden, J. and Fjers, H.: Expression and characterization of the product of a human immune interferon CDNA gene in Chinese hamster cvary cells. Proc. Natl. Acad. Sci. USA 80. 4654-4658, (1983).

6. Lasky, L.A., Dowbenko, D., Simonsen, C., and Berman, (1984): Production of an HSV Subunit Vaccine by genetically engineered mammalian cell lines. In: CSH "Hew approaches to vaccines, Vol. p. 189-194.

7. Moriarty, A.M., Hoyer, B.H., Shih, I.H., Gerin, J.L., and Hamer, D.H. (1981). Expression of the hepatitis $B$ virus surface antigen gene in cell culture by using simian virus 40 vector. Proc. Matl. Acad. Sci. USA 78, 2606-2610. 
8. Mulligan, R.C., Howard, B.H., and Berg, - (1979). Jynthesis of rabbit beta- globin in cultured monkey kidney cells following transfection with a Sv40-beta-globin recombinant genome. Nature 277, 108-114.

9. Sarver, N., Gruss, P., Law, M.F., Khoury, G., and Howley, P.M. (1981) Bowine Papilloma Virus Deoxyribonucleic Acid: a novel eucaryotic cloning vector. Mol. Cell. Biol. 1, 486-496.

10. Tabin, C.J.. Hoffmann, J.W., Goff, S.P., and Weinberg, R.A. (1982) Adaptation of a retrovirus as a eucaryotic vector transmitting the Herpes simplex Virus Thymidine Kinase Gene, Mol Cell. Biol. 2, 426-4367.

11. McCormick F., Trahey, M, Innis, M., Dieckmann, B., and Ringold, G.: Inducible expression of amplified human beta interferon genes in $\mathrm{CHO}$ cells. Mol. Cell. Biology 4,1, 166-172, (1984).

12. Page, M.J.: Expression of amplified human beta interferon genes using heavy metal induction in Chinese hamster ovary cells. Gene 37, 139-144 (1985).

13. Karin, M. Cathala, G., and Nguyen-Huu, M.C.: Expression and regulation of a human metallothionein gene carried on an autonomously replication shuttle vector. Proc. Mat1. Acad. Sci. USA BO, 4040-4044, (1983).

14. Lee, F. Mulligan, R., Berg, P., and Ringold, G.: Glucocorticoids regulate expression of ihydrofolate reductase cDNA in mouse mamary tumor virus chimaeric plasmids. Nature, 294, 228-232, (1981).

15. Papkoff, J. and Ringold, G.M.: Use of the mouse manmary tumor virus long teminal repeat to promote steroid inducible expression of -mos. J. Virology, 52, 2, 420-430 (1984).

16. Hamer, D.H. and Walling, M.J. (1982). Regulation in vivo of a cloned mammalian gene: Cadmium induces the transcription of a mouse metallothionein gene in SV40 vectors. J.Mol. Appl. Genets. 1, 273-288. 
17. Livak, K.F. Freund, R., Schweber, M., Wensink, P.C. and Meselson, M. (1978): Sequence organization and transcription of two heat shock loci in Drosophila. Proc. Natl. Acad. Sci. USA 75, 5613-5617.

18. Holmgren, R., Livak, K., Morimoto, R., Freund, R. and Meselson, M.(1979): Studies of cloned sequences from four Drosophila heat shock loci. Cell, $18,1359-1370$.

19. Kingston, R.A. and Gwinn, K. (1985) unpublished observation.

20. Mirault, M.E., Southgate, R. and Delwart, E. (1982): Regulation of heat-shock genes: a ONA sequence upstream of Drosophila hsp 70 genes is essential for their induction in monkey cells. EMBO J. 1, 10, 1279-1285.

21. Weinberg, R.A. (1985): The action of oncogenes in the cytoplasm and nucleus. Science $230,770-776$.

22. Dean, M., Levine, R.A., and Campisi, J. (1986): c-myc regulation during retinoic acid-induced differentiation of $F 9$ cells is post-transcriptional and associated with growth arrest. Mol. Celi. Biol. 6,2, 518-524.

23. Adams, J.M., Harris, A.H., Pinkert, C.A., Corcoran, L.M., Alexander, H.S., Cory, S, Palmiter, R.D., and Brinster, R.L. (1985): The C-myc

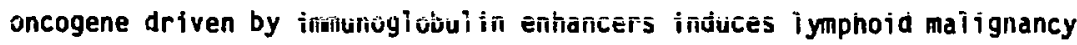
in transgentc mice. Nature 318, 533-539.

24. Erikson, J. Miller, O.A., Miller, O.J., Abcarian, P.H., Skurla, R.M.. Mushinski, J.F., and Croce, C.M. (1985): The C-myc oncogene is translocated to the involved chromosome 12 in mouse plasmacytoma. Proc. Nat1. Acad. Sci. 82, 4212-4216.

25. Schwab, M., Ramsay, G. Alitalo, K. Varmus, H.E., Bishop, J.M., Martinson, T., Levan, G. and Levan, A. (1985): Amplification and enhanced expression of the c-myc oncogene in mouse SEWA tumor cells. Nature 315, 345-347. 
26. Selten, G., Cuypers, H.T., Zijlstra, M. Melief, C., and Berns, A. (1984):

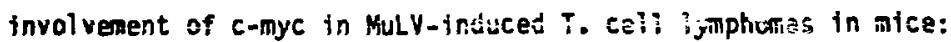
frequence and mechanisms of activation. Embo J. 3, 13, 3215-3222.

27. Unpublished observtion: Bob Kingston, Phil Sharp.

28. Urlaub, G. and Chasin, L.: Isolation of Chinese hamster cell mutants deficient in dihydrofolate reductase activity, Proc. Natl. Acad. Sci. USA 77, 4216-4220 (1980).

29. Kaufman, R.J. and Sharp, P.A.: Amplification and expression of sequences cotransfected with a modular dihydrofolate reductase complementary DNA gene. J. Mol. Biol. 159, 601-602 (1982).

30. Schimke, R.T.: Gene amplification in cultured animal cells. Cell 37, 705-713 (1984).

31. MeGarry, T.J., and Lindquist, S. (1985): The preferential translation of Drosophila hsp 70 mRNA requires sequences in the untranslated leader. Ce11 42, 903-911.

32. Amin, J., Mestril, R., Lawson, R., Klapper, J., and Voellmy, R. (1995): The heat shack consensus sequence is not sufficient for hsp 70 gene expression in Drosophila melanogaster. Mol. Cell. Biol. 5,1, 197-203.

33. Corces, U., and Pellicer, A. (1984) Identification of sequences involved in transcriptional control of a Drosophila heat shock gene. J. Biol. Chen. 259, 14812-14817.

34. Topol, J, Ruden, D.M., and Parker, C.S. (1985): Sequences required for in vitro transcriptional activation of a Drosophila hsp 70 gene. Cell $42,527-537$. 
35. Stanton, L.W., Watt, R. and Marcu, K.B.: (1983) Translocation, breakage and truncated transcripts of c-myc oncogene in murine plasmacytomas, Nature 303, 401-406.

36. Stanton, L.W., Fahrlander, P.D., Tesser, P.M., and Marcu, R.B. (1984): Nucleotide sequence comparison of nomal and translocated murine c-myc genes. Nature 310, 423-425.

37. Kingston, R.E., Kaufman, R.J. and Sharp, P.A. (1984) Regulation of transcription of the Adenovirus Ell promoter by Ela gene proucts: Absence of sequence specifity. Mol. Cel. Biol. 4, 1970-1978,

38. Simcox, A.A., Cheney, C.M., Hoffman, E.P., and Shearn, A. (1985): A deletion of the $3^{\prime}$ end of the Drosophila melanogaster hsp 70 gene increases stability of mutant mRNA during recovery from heatshock. Mol. Cell. Biol. 5, 22, 3397-3402.

39. Hann, S.R. and Elsenman, R.K. (1984): Proteins encoded by the human c-myc oncogene: Differential expression in neoplastic cells. Mol. Cel?. Biol. 4, 11, 2486-2497.

40. Persson, H. Gray, H.E., and Godeau, F. (1985): Growth dependent synthesis of c-myc encoded proteins: Early stimulation by serum factors in synchronized mouse 3T3 cells. Mol. Cell. Biol, 5, 1, 2903-2912.

41. Alitalo, K., Ramsay, G Bishop, J.M., Pfeifer, S.O., Colby, W.H., and A.D. Levinson (1983): Identification of nuclear proteins encoded by viral and cellular myc oncogenes. Nature 306, 274-277.

42. Hann, S.R., Abrams, H.D., Rohrschneider, L.R. and Eisenman, R.N. (1983): Proteins encoded by u-myc and c-myc oncogenes: Identification and localization in Acute Leukemia Virus transformants and bursal lymphoma cell lines. Cell 34, 789-798. 
43. Parag, H.A. Raboy, B. and Kulka, R.G. (1987): Effect of heat shock on protein degradation in mamalian cells: involvement of the ubiquitin system. Embo J. 6,1, 55-61.

44. Ramsay, G. Evan, G.I.., and Bishop, J.M. (1984): The protein encoded by the human proto-oncogen c-myc. Proc. Natl. Acad. Sci. USA 81, 7742-7746.

45. Miyamoto, C., Chizzonite, R., Crowl, R., Rupprecht, K., Kramer, R., Schaber, M., Kumar, G., Poonian, M., and Ju, G. (1985): Molecular cloning and regulated expression of the human $c-m y c$ gene in Escherichia coli and Saccharomyces cerevisiae: Comarison of the protetn roducts. Proc. Nat1. Acad. Sci. USA 82, 7232-7236.

46. Arathoon, H.R. and Birch, J.R. (1986): Large scale cell culure in biotechnology, Science 232, 1390-1395.

47. Pelham, H.R.B. (1982): A regulatory upstream pronoter element in the Drosophila hsp70 heat-shock gene. Cell 30, 517-528. 


\section{LEGERS TO FIGURES}

\section{FIGURE 1}

Plasmids used to establish reccmbinant myc lines:

A. Expression vector pHS-Myc: This plasmid contains a genomic mouse c-myc fragnent from a unique Xbal site 48 bp upstream of the translation start codon in exon 2 to the unique BamHI site about $2.5 \mathrm{~kb}$ downstream of exon 3. The filled boxes denote the c-myc coding region and the light dotted boxes denote the remainder of mouse c-myc genomic sequences. The open box denotes the Drosophi? a hsp70 promoter region, and the arrow denotes the start site of transcription. The fusion between the promoter region and the c-myc gene is at +88 of the $5^{4}$ untranslated region of the hsp70 promoter.

B. DHFR selection vecter PCVSVEII-OHFR (37): The DHFR coding region is denoted by the solid box, spifice and polyadenylation signals are denoted by the hatched box, and the adenovirus EII promoter and SV40 enhancer region are contalned in the area denoted by the open box.

\section{FIEURE 2}

Copy number of c-myc constructs in recombinant $\mathrm{CHO}$ cell lines:

Genomic DNA isolated from four different recombinant cell lines growing at $320 \mu \mathrm{M}$ methotrexate (1anes 6-9, $2 \mu \mathrm{g}$ each), or from the cell 1 ine 
r. A HS MYC growing at different levels of methotrexate (1 anes 13-16, $0.5 \mu \mathrm{g}$ each) was restricted to complet.ion with HindIII and together with HindII restricted dilutions of the plasmid pHSmyc (1anes 1-4): 20ng, $6 \mathrm{ng}, 2 \mathrm{ng}, 0.6 \mathrm{ng}$ and 1 anes 10-12: $4 \mathrm{ng}, 1.3 \mathrm{ng}, 0.45 \mathrm{ng})$ subjected to agarose gel electrophoresis and Southern transfer to Genescreen Plus membranes (NEN). The membranes were then hybridized to SP6 polymerase in-vitro synthesized ${ }^{32} \mathrm{P}-\mathrm{R} N A$ conststing of the sequences of the PstI-HindIII fragment containing c-nyc exonxx 2, intron 2 and exon 3. The last lane on the right contains radiolabelled $1 \mathrm{~kb}-1$ adder DHA (BRL).

\section{FIGURE 3}

$A$ and $B$ : Presence, inducibility and stability of c-myc mRNA in recombinant CHO cells.

Cytoplasmic RNA from uninduced (-) and heat shock induced (2 hours at 43 $C,+)$ recombinant ceils was analyzed using an internally iabelled RNA probe (shown in 8) on a $10 \%$ denaturing polyacrylamide gel (lanes 1-10) or on $6 \%$ non-denaturing polyacrylamide gels.

A. Lanes 1-10; RNA samples $(10 \mu g)$ from recombinant cell 1 ines (as indicated) in 0 methotrexate were analyzed, Lanes 11-16; RNA samples (5 $\mu \mathrm{g})$ from the line $5 \mathrm{~A}$ HS MYC growing at different levels of methotrexate were analyzed. 
B. RNA Samples ( $3 \mu g$ ) from line 4 HS-MYC (lanes 1-4), 5A HS-MYC (lanes 5-8) and CHO-DUKX (lanes 9 and 10) were analyzed as in A. RNA was isolated from cells growing at $37^{\circ} \mathrm{C}(1$ anes 1,5 , and 9), or from cells that had been incubated at $43^{\circ} \mathrm{C}$ for 2 hours and allowed to recover at $37^{\circ} \mathrm{C}$ for 1 hour (1 anes 2 and 6$), 2$ hours ( 1 anes 3,7 and 10) or 3 hours ( 1 anes 4 and 8). An SPG RNA polymerase generated transcript containing the sequences of the hsp 70 promoter from PstI $(+88)$ to HindIII $(-700)$ was used as probe. The bands labelled $5^{\prime}$ end migrate at 90 bases in denaturing gels.

\section{FIGURE 4}

$A$ and B: Time course of induction of c-myc protein and analys is of protein levels in induced cells.

Levels of c-myc protein in cell lines growing at $37^{\circ} \mathrm{C}$ (A: lanes 1, 5, 9 , 11; B: Ianes $1,3,7$, ) and after heat shock induction for $2 \mathrm{~h}$ at $43^{\circ} \mathrm{C}$ and varying time periods of recovery at $37^{\circ} \mathrm{C}$ ( $\mathrm{A}$ : 1 anes 2 and 6,1 hour recovery; lanes 3,7 , and 10, 2 hours recovery; Ianes 4 and 8,3 hours recovery. B: lane 4, 1 hour recovery; lanes 2 and 5, 2 hours recovery; lane 6, 3 hours recovery). RIPA buffer lysates ( 2 mil) were prepared from $2 \times 10^{7}$ cells. Samples $(20 \mu 1)$ were analyzed by imunoblotting using anti C-myc monoclonal antibodies (R. Chizzonice, Hoffmann-La Roche) and ${ }^{125}$ Iodine labelled Protein A (NEN). In B, lanes 8 and 9 contain purified c-myc (1ane 8;10 ng lane 9; $50 \mathrm{ng}$ ) dervied from recombinant insect cells (G. Ju, Hoffmann-La Roche). 
c. The c-myc protein is one of the major proteins synthesized in the recombinant lines during recovery and is made as a phosphoprotein.

RIPA buffer lysates of ${ }^{35} \mathrm{~S}$ methionine (1anes 1-4:400 000 cm/ $/$ ane) and 35 phosphate labelled proteins (lanes 5-10): $400000 \mathrm{cpm} / 1$ ane, imunopreciptiation: lanes 11-17) were separated on 12\% SOS-PAGE. Protein isolates were from the Indicated cell line either growing at $37^{\circ} \mathrm{C}$ $(-)$ or induced for 2 hours at $43^{\circ} \mathrm{C}(+)$ and al lowed to recover at $37^{\circ} \mathrm{C}$ for either 2 hours ( 1 anes $2,4,6,9,12$ and 15) or hours ( 1 anes $7,10,13$, 16, and 17). Lane 17 is a light exposure of 1 ane 16.

\section{FIGURE 5}

Overexpression of c-myc is cytotoxic.

A) $100 \mathrm{~mm}$ petridishes seeded with parental or recombinant CHO cells at about $10 \%$ confluency were heat shocked for 2 hours at $43^{\circ} \mathrm{C}$ and recovered for 3 daysat $37^{\circ} \mathrm{C}(b, d)$ or left at $37^{\circ} \mathrm{C}$ all the time $(a, c)$. Petridishes were stained with alcoholic cristalviolett solution (1x).

B. Micrographs from approximately $50 \%$ confluent CHO-DUKH BI cells (a-d) and from recombirant cell line 4 HS MYC (e-h) before heat shock and after different pertods of recc.ery after heat shock as indicated. 


$$
\text { Fiy } 1
$$

pHS-MYC

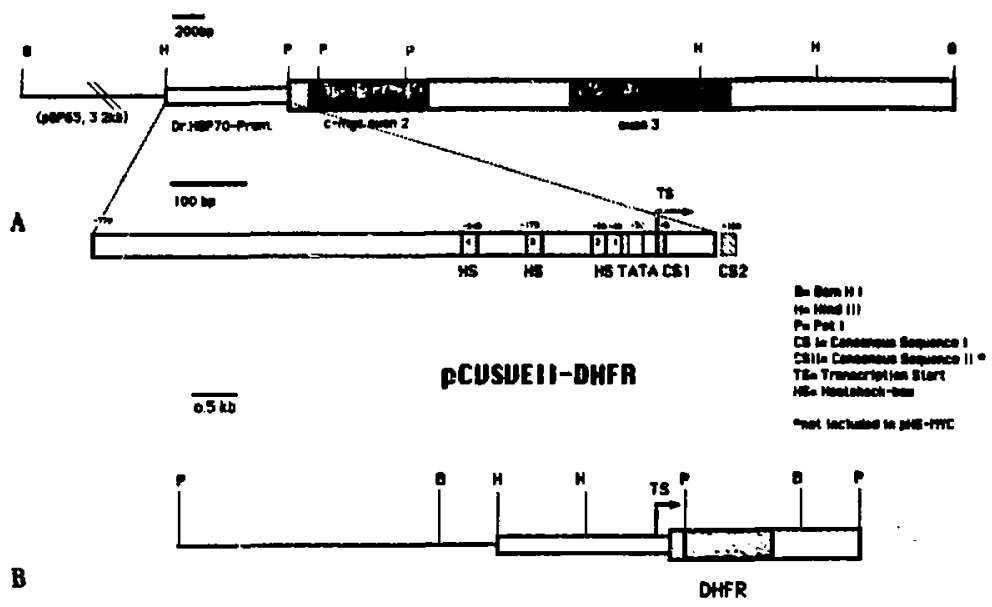


Fig 2

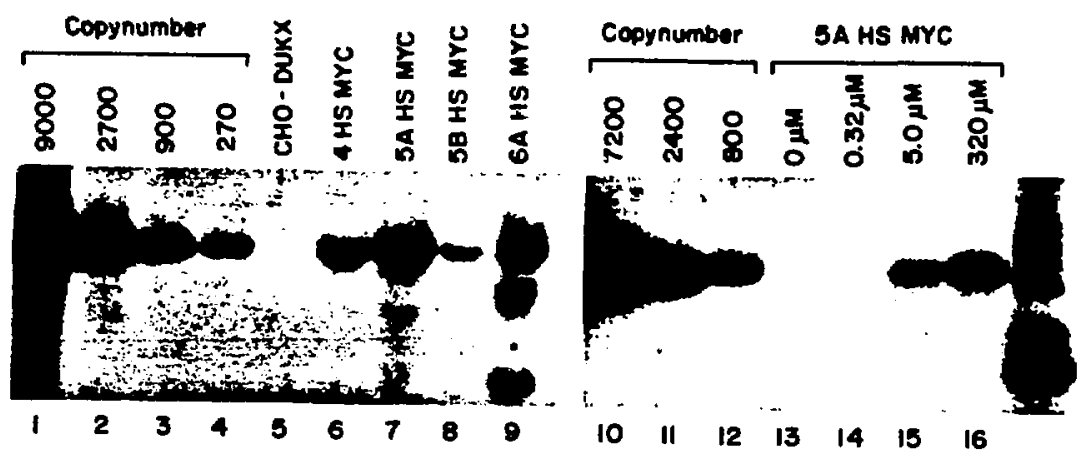




$$
\text { Fig } 3
$$

A
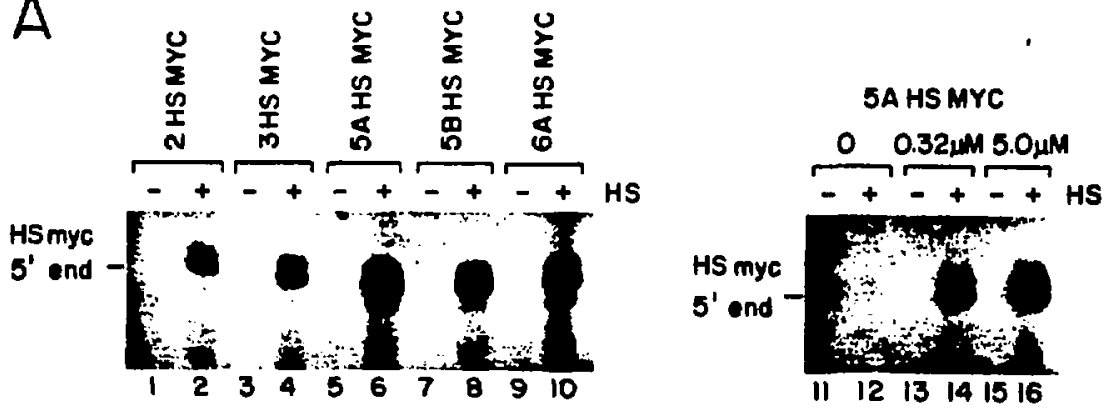

B
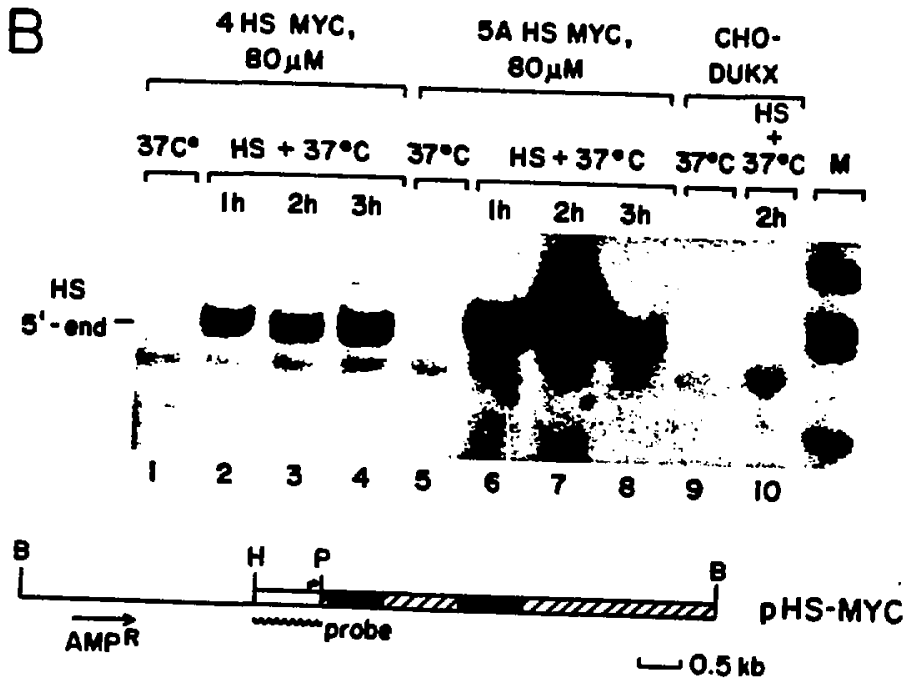
Fig 4
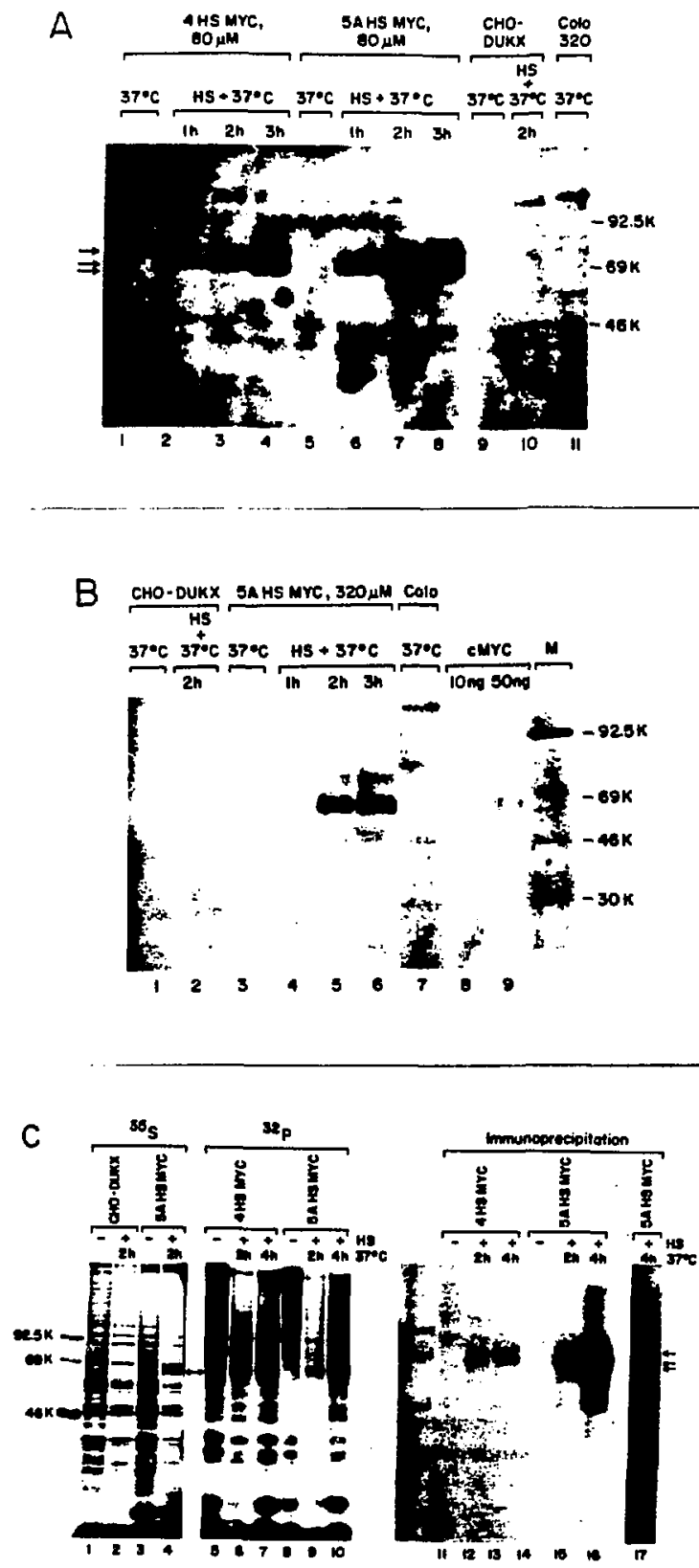


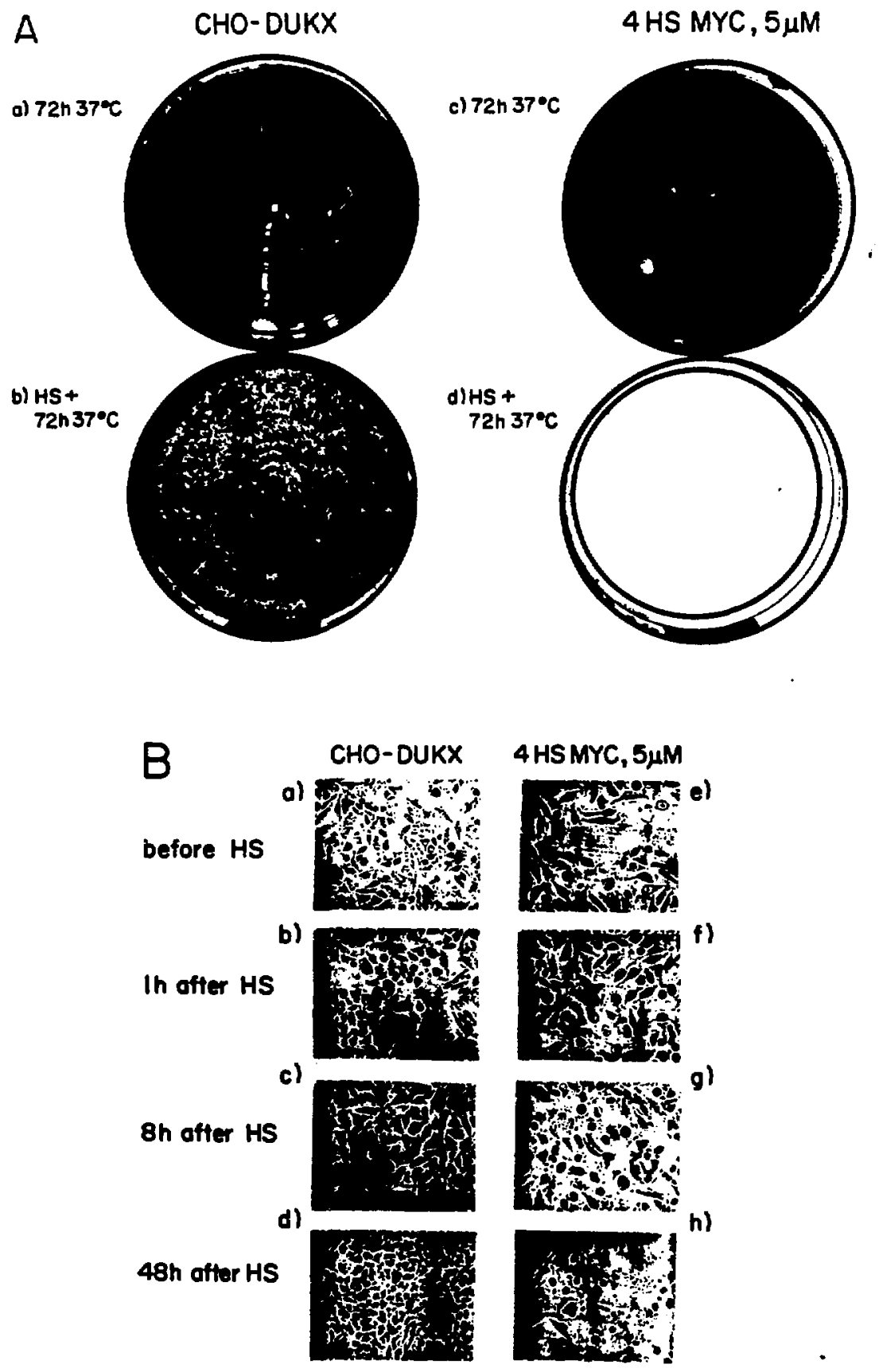

